\title{
The Role of Courage in Intellectual Work*
}

\author{
Liliana Beatriz Irizar \\ Department of Philosophy, Sergio Arboleda University, Bogotá, Colombia \\ Email: liliana.irizar@usa.edu.co
}

Received 17 March 2014; revised 15 April 2014; accepted 12 May 2014

Copyright (C) 2014 by author and Scientific Research Publishing Inc.

This work is licensed under the Creative Commons Attribution International License (CC BY). http://creativecommons.org/licenses/by/4.0/

(c) (i) Open Access

\begin{abstract}
Intellectual life is not a thing apart from the humanizing and moralizing influences that moral virtues provide. Saint Thomas's teachings about moral virtues suggest how essential he considers them for a flourishing speculative life. He makes all this very clear in the Second Part of the Summa Theologiae. The potential parts of fortitude which have a crucial role in intellectual work are patience, perseverance and magnanimity. In this article I show how these potential virtues act in speculative life.
\end{abstract}

\section{Keywords}

Moral Virtues, Intellectual Work, Courage, Patience, Constancy, Perseverance, Magnanimity, Presumption, Ambition, Vainglory, Obstinacy, Arrogance, Aristotle, Saint Thomas Aquinas

\section{Introduction1: Virtues Have a Constitutive Relevance in Intellectual Work}

As it is well known, research work is not free of the effects of disturbing emotions. In general, the researchers' concerns deal with truth, but quite often we experience contradictory feelings. In fact, the love of truth is not sufficient to hinder boredom and discouragement, which are frequently involved in intellectual work.

Accordingly, we may assume that intellectual life is indeed not a thing apart from the humanizing and moralizing influences that moral virtues provide. Good habits may enhance intellectual activity as far as perfecting will and emotions.

Saint Thomas's teachings about moral virtues suggest how essential he considers them for a flourishing speculative life. He makes all this very clear in the Second Part of the Summa Theologiae.

Thomas teaches that the virtue of fortitude “... is chiefly about fear of difficult things, which can withdraw the will from following the reason” (Aquinas, 1947: II-II, q.123, a.3).

\footnotetext{
${ }^{*}$ An Approach Based in Saint Thomas's Teachings, Paper presented in the 44th INTERNATIONAL CONGRESS ON MEDIEVAL STUDIES, Kalamazoo, May 2008 (Unpublished).

${ }^{1} \mathrm{ST}=$ Summa Theologiae.
} 
But, in accordance with Aquinas's analysis, it is necessary to distinguish potential parts in the virtue of courage. Whereas fortitude practices its main acts (to attack and to endure) in face of the greatest hardships, namely the danger of death, potential virtues practice these acts in presence of certain minor hardships. The potential parts of fortitude which have a crucial role in intellectual work are patience, perseverance and magnanimity. Each one of them accomplishes a different beneficial influx on intellectual work.

In the following pages I will explore how these potential virtues act in speculative life.

\section{To Resist with Firmness in the Pursuit of Truth}

Every man who has engaged in the pursuit of truth knows that it is a fascinating undertaking. Even so, he also knows that this endeavor demands so much effort that it can become very painful.

Whoever has undertaken a hard and long-lasting research, knows what kind of difficulties and pains are involved in that task.

Certainly, we should admit that intellectual labor involves charm and appeal'2; otherwise it would not be possible to explain why so many people choose researching as a style of life, in spite of the dryness that it entails.

However, intellectual work brings with it some moments of discouragement and a different sort of sorrows. Thus, the researcher ought to learn to constrain fear in order to face these and other so called "evils" which are linked to intellectual life, such as the intense and extraordinary effort required by the work, or the possibility of failure. Precisely, fortitude and its potential parts can free us from being dominated by those fears and help us endure our "private battles" until the end. To summarize what Thomas writes in the ST, II-II, q. 123, a. 3, we can say that fortitude is chiefly about fear of difficult things and daring refers to them. So, fortitude curbing fear and moderating daring.

“ $\cdots$ fortitude is chiefly about fear of difficult things, which can withdraw the will from following the reason. And it behooves one not only firmly to bear the assault of these difficulties by restraining fear, but also moderately to withstand them, when, to wit, it is necessary to dispel them altogether in order to free oneself there from for the future, which seems to come under the notion of daring. Therefore fortitude is about fear and daring, as curbing fear and moderating daring.” (Aquinas, 1947: II-II, q.123, a.3).

We can start analyzing the passion of sorrow, which could also be called sadness, in order to see the crucial influx exercised by patience, a potential part of fortitude which allows us to bear sadness calmly. That is why it is a part of fortitude, i.e., patience helps us to practice what is good with firmness and not stray away from it because of sorrow. Aquinas's teachings on patience can be found in the ST II-II, q. 136.

As Aquinas says:

" $\cdots$ the moral virtues are directed to the good, inasmuch as they safeguard the good of reason against the impulse of the passions. Now among the passions sorrow is strong to hinder the good of reason, according to 2 Cor. 7:10, 'The sorrow of the world worketh death,' and Ecclus. 30:25, 'Sadness hath killed many, and there is no profit in it.' Hence the necessity for a virtue to safeguard the good of reason against sorrow, lest reason give way to sorrow: and this patience does. Wherefore Augustine says (De Patientia ii): 'A man's patience it is whereby he bears evil with an equal mind,' i.e. without being disturbed by sorrow, 'lest he abandon with an unequal mind the goods whereby he may advance to better things.'” (Aquinas, 1947: II-II, q. 136, a.1).

The sorrow which impedes intellectual work can stem from:

1) The intellectual activity itself when it is painful under certain aspects. We can think about a very difficult subject or some dry matter for example our own bodily limitations such as tiredness, listlessness and physical illness and spiritual ones like worries and any sort of grief. Certainly, there is a quite common sorrow which affects the researcher; it is the sadness which comes from a fruitless task, at least for the time being.

In these cases sorrow leads us to forsake the painful task or to do it in a deficient way.

2) Any difficulty external to the intellectual operation itself. In this situation, significant sadness inhibits in-

\footnotetext{
${ }^{2}$ Thus, in (Aquinas, 1947: II-II, q. 182, a.1) we are told that "the contemplative life is more delightful than the active”. We should remember the deepest reason of this delight: "the contemplative life is according to that which is most proper to man, namely his intellect."
} 
tellectual activity because sorrow absorbs the soul's attention and fixes it on the cause of the pain ${ }^{3}$. Hence, the mental concentration about other subject-matters diminishes and may even stop. We should remember Saint Thomas's teaching:

"External pain arises from hurt done to the body, so that it involves bodily transmutation more than inward sorrow does: and yet the latter is greater in regard to the formal element of pain, which belongs to the soul. Consequently bodily pain is a greater hindrance to contemplation which requires complete repose, than inward sorrow is. Nevertheless if inward sorrow be very intense, it attracts the intention, so that man is unable to learn anything for the first time: wherefore on account of sorrow Gregory interrupted his commentary on Ezechiel (Hom. xxii in Ezechiel).” (Aquinas, 1947: I-II, q, 37, a.1, ad. 3).

In both situations patience helps us to overcome hindrances and allows us to continue the activity that was begun as perfectly as possible.

What this clearly displays is how necessary the virtue of patience is for intellectual life. Indeed a patient attitude is one of the main demands of human knowledge.

Intelligence requires a certain amount of time for ideas to be clear. If one attempts to force the process, one ends up doing a bad job by either not being able to complete the task or by having completed it badly.

In the same way, there is another part of courage, perseverance, which is an indispensable virtue for maintaining the amount of effort required to fulfill a difficult and lengthy task ${ }^{4}$.

This virtue, in effect, helps us to solidly maintain our interest in the task until it is done.

Perseverance strengthens irascibility towards a certain type of difficulty: the extended durability of the task. Even though, in the end, the obstacle here consist fundamentally of the physical tiredness and the spiritual exhaustion that lasting effort involves. As Aquinas says, perseverance “... moderates certain passions, namely fear of weariness or failure on account of the delay” (Aquinas, 1947: II-II q.137, a.2, ad 2).

Perseverance, therefore, protects us against fatigue and allows us to triumph over laziness.

Constancy ${ }^{5}$ is another potential part of courage. This virtue fortifies our will and helps it to overcome hindrances that are foreign to research tasks. Quite often we may be tempted to abandon our projects, for example, due to insufficient economic resources; not having enough time to investigate, or the absence of the adequate human atmosphere that benefits flourishing intellectual life. The constant man or woman does not give in to these obstacles before seriously trying to overcome them. It could be said that constancy transforms our views about certain situations because it allows us to see them as challenges rather than as difficulties.

The pursuit of truth must be the main goal of the researcher. Because of this, we should consider another important potential part of fortitude, magnanimity, which is closely linked to intellectual work.

Magnanimous people are those who have "big souls". Certainly, their souls are big, as are their aims ${ }^{6}$. Magnanimity is about the pursuit of great honors which result from an ethical flourishing life ${ }^{7}$.

In fact, their desires enlarge their spirits. Indeed, magnanimity shapes our hope ${ }^{8}$, which is an emotion that induces us to undertake ambitious projects in so far as they are glimpsed as attainable.

Precisely, virtue is always a mean. Therefore, it protects us from excesses as much as from deficient acts which hinder our hope.

\footnotetext{
3“Since all the powers of the soul are rooted in the one essence of the soul, it must needs happen, when the intention of the soul is strongly drawn towards the action of one power, that it is withdrawn from the action of another power: because the soul, being one, can only have one intention. The result is that if one thing draws upon itself the entire intention of the soul, or a great portion thereof, anything else requiring considerable attention is incompatible therewith" (Aquinas, 1947: I-II, q. 37, a.1).

4،... to persist in good for a long time until the end, belongs to a special virtue called perseverance, which intends this as its special end” (Aquinas, 1947: II-II, q. 137, a. 1, ad 3).

5“... constancy makes him persist firmly in good against difficulties arising from any other external hindrances” (Aquinas, 1947: II-II, q. 137 a. 3).

6 “. $\cdots$ there are two virtues about honors, one about ordinary honors. This virtue has no name $(\cdots)$ But with regard to great honors there is magnanimity. Wherefore we must conclude that the proper matter of magnanimity is great honor, and that a magnanimous man tends to such things as are deserving of honor” (Aquinas, 1947: II-II, q. 129, a. 2).

7"Magnanimity is not about any kind of honor, but great honor. Now, as honor is due to virtue, so great honor is due to a great deed of virtue Hence it is that the magnanimous is intent on doing great deeds in every virtue, in so far, to wit, as he tends to what is worthy of great honors" (Aquinas, 1947: I-II, q. 129, a. 4, ad 1).

8“'Although honor is neither a passion nor an operation, yet it is the object of a passion, namely hope, which tends to a difficult good. Wherefore magnanimity is immediately about the passions of hope, and mediately about honor as the object of hope *..” (Aquinas, 1947: II-II, q. 129, a. 1, ad 2).
} 
Saint Thomas distinguishes (Aquinas, 1947: II-II, qq. 129-133) five opposing vices to magnanimity: presumption, ambition and vainglory (which are in opposition by excess) and pusillanimity (which is in opposition by deficiency).

Ambition $^{9}$ and vainglory ${ }^{10}$ can be defined as the disordered desire to become a notorious and celebrated man or woman. In other words, both vices involve the futile tendency to achieve success and be renowned.

In fact, the one most relevant impediment to attaining the truth is precisely this frivolous attitude. Frivolity, indeed, leads us astray from the calmness and deepness which are demanded by pursuit of truth.

Besides that, the researcher who acts under such pressures runs the risk of betraying their convictions. It is relatively easy when the desire to please everybody in order to gain popularity is more intense than the love of truth. But, as Aristotle teaches, the magnanimous are free from this demand thanks to their virtue (Aristotle, 2009: IV, 1124b25-30).

It is also noteworthy that the researcher's ambition and vainglory quite often induce him or her to give more relevance to the style of writing than the content. We should not forget the wise ancient teaching from Plato ${ }^{11}$. The ancient philosophers were well aware that the beauty and novelty of writing are the radiance of the truth itself.

Vainglory, in turn, involves another significant impediment in the pursuit of truth: obstinacy. The love of one's own superiority leads the conceited man or woman to cling to their ideas. They are persuaded that only they are right ${ }^{12}$. This intransigent attitude impedes the researcher in enriching their own knowledge through dialogue and academic debate.

Arrogance is also an opposing vice to magnanimity. Indeed, the arrogant person strays away from hope through excess due to overestimating their qualities and knowledge. Because of this they dare to approach subjects which surpass their capacities or intellectual possibilities ${ }^{13}$. The many wrong convictions the researcher has tend also to be rooted in arrogance. This amounts to the persuasion that only what they are able to understand and to demonstrate can be right. As Aquinas puts it:

“... There are some who have such a presumptuous opinion of their own ability that they deem themselves able to measure the nature of everything; I mean to say that, in their estimation, everything is true that seems to them so, and everything is false that does not.” (Aquinas, 2007: I, 5).

Lastly, we have pusillanimity, a vice which leads us astray from hope through a deficient attitude. The fainthearted person underestimates their intellectual capacities and assets ${ }^{14}$, consequently, impeding themselves from achieving certain aims which they would be able to accomplish ${ }^{15}$. Ironically, the hopeless person is defeated by the fear of failing right from the beginning. We understand here why both Aristotle and Saint Thomas claim that pusillanimity is worse than arrogance because the former exerts a stopping influx on human activity. Hence pu-

\footnotetext{
9 “... the desire of honor may be inordinate in three ways. First, when a man desires recognition of an excellence which he has not: this is to desire more than his share of honor. Secondly, when a man desires honor for himself without referring it to God. Thirdly, when a man's appetite rests in honor itself, without referring it to the profit of others. Since then ambition denotes inordinate desire of honor, it is evident that it is always a sin” (Aquinas, 1947: II-II, q. 131, a. 1).

${ }^{10}$ It is the case of “ $\cdots$ the man himself who seeks glory, for that he does not refer the desire of his own glory to a due end, such as God's honor, or the spiritual welfare of his neighbor” (Aquinas, 1947: II-II, q. 132, a. 1).

${ }^{11}$ Plato, 1997: 268 a y ss.

12 “... as regards the intellect, and thus we have 'obstinacy', by which a man is too much attached to his own opinion, being unwilling to believe one that is better” (Aquinas, 1947: II-II, q. 132, a. 5).

13، Since whatever is according to nature, is ordered by the Divine Reason, which human reason ought to imitate, whatever is done in accordance with human reason in opposition to the order established in general throughout natural things is vicious and sinful. Now it is established throughout all natural things, that every action is commensurate with the power of the agent, nor does any natural agent strive to do what exceeds its ability. Hence it is vicious and sinful, as being contrary to the natural order, that any one should assume to do what is above his power: and this is what is meant by presumption, as its very name shows. Wherefore it is evident that presumption is a sin" (Aquinas, 1947: II-II, 130, a.1).

${ }^{14}$ “Whatever is contrary to a natural inclination is a sin, because it is contrary to a law of nature. Now everything has a natural inclination to accomplish an action that is commensurate with its power: as is evident in all natural things, whether animate or inanimate. Now just as presumption makes a man exceed what is proportionate to his power, by striving to do more than he can, so pusillanimity makes a man fall short of what is proportionate to his power, by refusing to tend to that which is commensurate thereto. Wherefore as presumption is a sin, so is pusillanimity. Hence it is that the servant who buried in the earth the money he had received from his master, and did not trade with it through fainthearted fear, was punished by his master (Matthew 25; Luke 19)” (Aquinas, 1947: II-II, q. 133, a. 1).

15 ،... the fainthearted is worthy of great things in proportion to his ability for virtue, ability which he derives either from a good natural disposition, or from science, or from external fortune, and if he fails to use those things for virtue, he becomes guilty of pusillanimity" (Aquinas, 1947: II-II,q. 133, a. 1, ad 2).
} 
sillanimity impedes us from practicing good acts (Aristotle, 2009: IV, 3, 1124a25-1125b1).

Now, we begin to see the main traits characterizing the magnanimous person's attitude towards intellectual work. They pursue what is actually worthy of being pursued: the truth. Thus, they esteem all things in their true value and do not let appearances mislead them ${ }^{16}$. They are aware of their qualities and limits. Consequently, they will work indefatigably to achieve their aims.

It could be said that the magnanimous enjoy a firm freedom. They are free ofexcessive ambitions and the consequent fears. This emancipated attitude allows them to clear the main obstacles in the path of truth.

Finally, I would like to make some mention of another virtue linked in an intimate way to fortitude: martyr$\boldsymbol{d o m}^{17}$. This special kind of manner of being courageous presupposes that there are certain things that should be loved more than our own lives, such as the truth.

Definitely, this is a virtue whose practice can be required of the researcher too, especially nowadays. Indeed, we live in an age in which serving the truth is challenging. However, the authentic researcher-particularly "one who seeks the truth" (John Paul II, 1998: n 28)—should prefer to lose their life rather than to agree to falsehood and error.

Quite often, the researcher is obliged to face serious and subtle dilemmas if they want to maintain their commitment to the truth and its demands. They may be tempted to silence some controversial truths in exchange for having their works published; obtaining certain position and influence and so forth. The dilemma between loyalty to the truth and the possibility of "intellectual ostracism" is one of the most crucial challenges for the researcher.

\section{Conclusions}

In this paper I have explored the close relationship between the virtue of courage and intellectual work.

The task of searching for the truth requires really ceaseless effort because in its absence, as John Paul II has taught, "The inconstancy of the heart often obscures and distorts a person’s search” (John Paul II, 1998: N 28).

Courage and its potential parts enable the researcher to maintain their search with determination, without either overvaluing or undervaluing their intellectual capacity. Such virtues allow the researcher to persistently rectify their aims and interests in the search for the truth, and thus avoid being misled.

Arriving at the truth is not a simple task. It entails the whole person (Aristotle, 1993: I, 4, 408b10-20), in consequence, not only intellectual virtues are required in order to conquer the truth, but also moral ones. Fortitude is one of them and one quite essential in order to assume with firmness the effort, and even some risks; the beautiful risks (Plato, 1997: 114c-d), Plato would say that the loyal love of the truth imposes.

\section{References}

Aquinas, T. (1947). Summa Theologia. (Fathers of the English Dominican Province, Translation). Benziger Bros. Edition. http://dhspriory.org/thomas/english/summa/index.html

Aristotle (1993). De Anima (D. W. Hamlyn, translation). Oxford: Oxford University Press.

Aristotle (2009). Nicomachean Ethics (O. University, Translation). Oxford: Oxford World’s Classics.

John Paul, II. (1998). Fides et ratio (Vatican Translation). Boston: Pauline Books and Media.

Plato (1997). Phedro. En Plato, Plato Complete Works (J. M. Cooper, Translation). Cambridge: Hackett Publishing Co, Inc.

\footnotetext{
16“'As stated above (II-II, q.103, a. 1, ad 3), glory is an effect of honor and praise: because from the fact that a man is praised, or shown any kind of reverence, he acquires charity in the knowledge of others. And since magnanimity is about honor, as stated above (II-II, 129 , a. 1 and a. 2), it follows that it also is about glory: seeing that as a man uses honor moderately, so too does he use glory in moderation. Wherefore inordinate desire of glory is directly opposed to magnanimity” (Aquinas, 1947: II-II, q.132, a.2).

${ }^{17}$ (Aquinas, 1947: II-II, q. 124, a. 2) “... it belongs to fortitude to strengthen man in the good of virtue, especially against dangers, and chiefly against dangers of death, and most of all against those that occur in battle. Now it is evident that in martyrdom man is firmly strengthened in the good of virtue, since he cleaves to faith and justice notwithstanding the threatening danger of death, the imminence of which is moreover due to a kind of particular contest with his persecutors".
} 
Scientific Research Publishing (SCIRP) is one of the largest Open Access journal publishers. It is currently publishing more than 200 open access, online, peer-reviewed journals covering a wide range of academic disciplines. SCIRP serves the worldwide academic communities and contributes to the progress and application of science with its publication.

Other selected journals from SCIRP are listed as below. Submit your manuscript to us via either submit@scirp.org or Online Submission Portal.
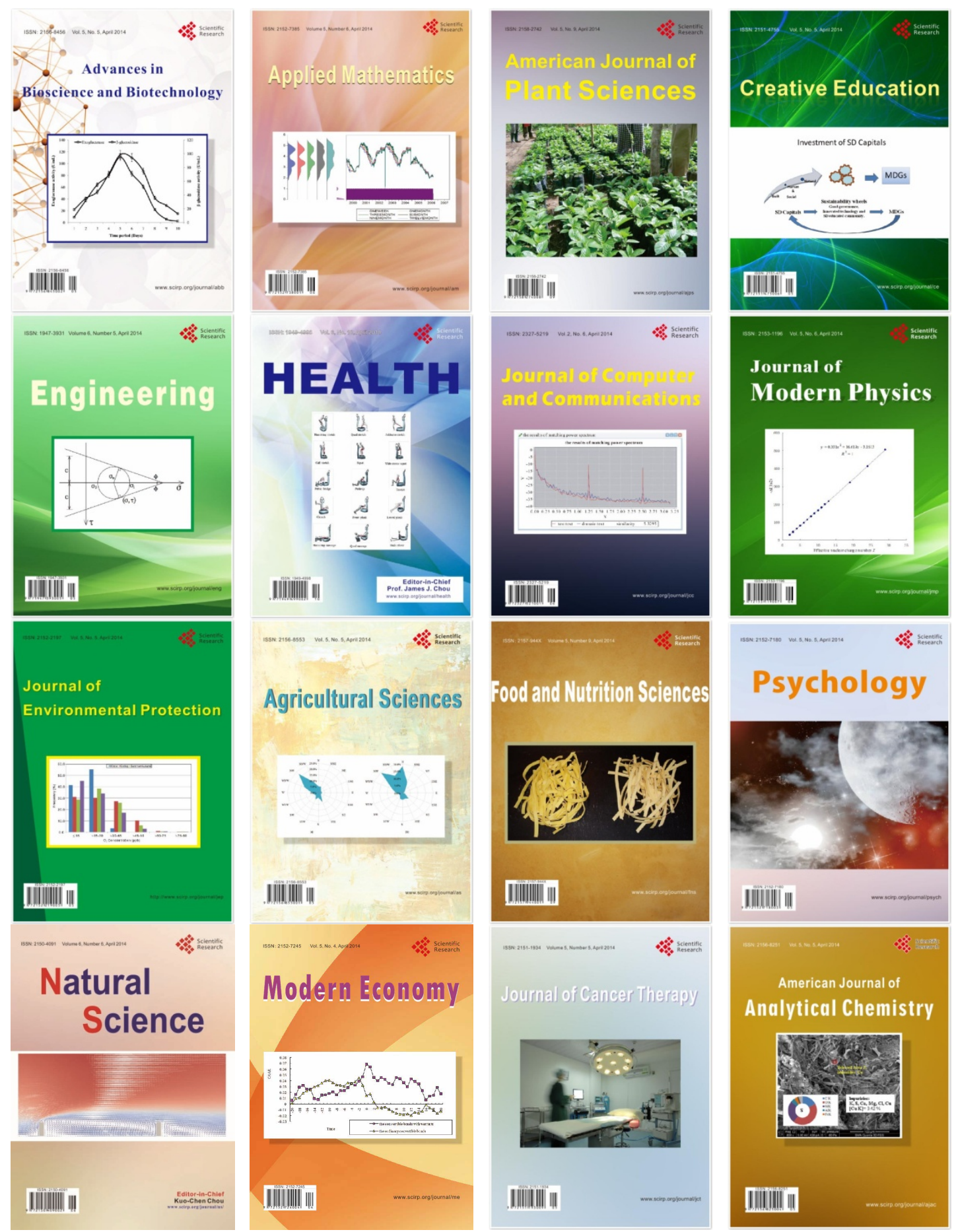